\author{
Maral Azizi \\ PhD Candidate in TEFL, English Language Instructor \\ English Language Department, Shiraz Branch, Islamic Azad University, Shiraz, Iran \\ Maralazizi.25@gmail.com \\ Ehsan Rassaei \\ PhD Candidate in TEFL, Assistant professor \\ English Language Department, Shiraz Branch, Islamic Azad University, Shiraz, Iran \\ Ehsanrassaei@yahoo.com \\ Mohammad Sadegh Bagheri \\ PhD Candidate in TEFL, Assistant professor \\ English Language Department, Shiraz Branch, Islamic Azad University, Shiraz, Iran \\ bagheries@gmail.com
}

\title{
MOBILE MEDIATED LEARNING IN LANGUAGE CLASSROOMS: LEARNER'S SATISFACTION, THEIR PERCEIVED USEFULNESS OF INSTRUCTION AND CLASSROOM ACHIEVEMENT
}

\begin{abstract}
Mobile technology has recently become one of the most important fields of study for many educators in the field of teaching and learning. Mobile technologies are considered as valuable resources for language learning and teaching and provide many practical applications for language learning. The concept of mobile mediated learning and its underlying constructs along with their implications for language learning and teaching are little understood in Iranian context. So, it is important to investigate how different aspects of mobile mediated learning including omnipresence, context customization, interactivity, perceived self-efficacy, and m-learning motivation affect second language learning. This paper investigates the understanding of mobile mediated language learning among Iranian English as a Foreign Language (EFL) learners by examining the effect of different aspects of this concept on learners' satisfaction with mobile learning as well as the learners' perception of usefulness of mobile learning. Moreover, this study aims to examine the effect of learners' perceived satisfaction and perceived usefulness of mobile learning on EFL learners' classroom achievement. To this end, a sample of 150 EFL learners were added to a Telegram group for 12 mobile-assisted language learning sessions and then answered three questionnaires regarding aspects of mobile mediated learning and also learners' perceived satisfaction and perceived usefulness of mobile learning. This study has a proposed research model that shows the constructs examined in this study. Structural equation modeling results indicated that two aspects of mobile mediated learning had a significant effect on learner's perceived satisfaction. The findings also showed that three aspects of mobile mediated learning affected learner's perceived usefulness of mobile learning. The results revealed that learner's classroom achievement is not influenced by learners' perceived satisfaction and perceived usefulness of mobile learning.
\end{abstract}

Keywords: mobile mediated learning; perceived satisfaction; perceived usefulness; classroom achievement.

\section{INTRODUCTION}

Statement of the problem. Technology has recently been utilized to both contribute to and enrich language learning. Teachers have adopted a wide range of technology forms to gain support for their teaching, increase students' involvement in the learning process, present a number of authentic examples of the target culture, and establish a connection between their classrooms and those in other countries where the target language is used. Even though technology has permeated our everyday life, researchers and practitioners have continually made enormous attempts to find ways, through which technology can be incorporated into education where language learning is regarded as one of those fields [1]. In particular, traditional teacher-oriented learning of educational environments have turned into individual 
self-directed learning; this reflects the constructivism paradigm which requires new learning methods such as mobile mediated language learning to prepare authentic and real-life situation for learners [2]. Mobile mediated language learning facilitates ubiquitous learning because it provides learners access to learning an instruction at anytime anywhere.

Analysis of recent research and publications. Among different forms of technology, mobile phones have significantly attracted researchers' attention. Considering this phenomenon, the confluence of electronic learning (e-learning), mobile learning (m-learning), mobile devices, and wireless technologies has made mobile mediated language learning feasible for learners anytime, anywhere. In fact, mobile learning accelerates innovation by integrating unique features such as ubiquity, self-directed learning, mobility, interactivity, personalization (context customization), accessibility, and portability into learning environments [3].

On the other hand, previous research has shown that two factors that can potentially affect m-learning are learners' satisfaction and perceived usefulness of instruction [4], [5]. An examination of the factors that affect second language (L2) learners' perceived satisfaction and perceived usefulness can have a vital part in gaining an understanding of the path to success in an m-learning situation and it is hoped that taking account of such variables will help to enhance learning experience.

The purpose of the article. In fact, while the use of mobile technology for language learning has gained momentum in various EFL contexts, the use of this technology for language learning is less popular in Iranian EFL context. Moreover, little is known about different factors that can moderate the effectiveness of mobile technology on L2 learners' classroom achievement and language learning. To this end, the present study intends to shed some light on different individual factors that affect learners' satisfaction and perceived usefulness of using mobile technology for language learning. These factors include omnipresence, context customization, interactivity, perceived self-efficacy, and m-learning motivation. The study also examines the effect of those factors on learners' achievement using structural equation modeling.

\section{THE THEORETICAL BACKGROUNDS}

\subsection{Technology and Language Learning}

Recently there has been much interest and attention put in information and communication technology in the area of teaching/learning process. Mobile-related technologies, particularly smartphones and tablets, prove to be a novel tool applicable in different methods and strategies. Mobile technologies regarded as highly advanced technological products are nowadays being utilized by a large and representative number of so-called "digital generation" in our daily life as well as in recreational and educational activities. In this way, mobile fosters a more motivating and personalized teaching/learning process. In case this technology is employed, the students' motivation will be boosted, leading to their greater engagement, and consequently better and faster learning of concepts/skills. Accordingly, using mobile devices in classroom context will result in increased collaborative actions and cooperation between student/student, student/teacher and student/class [6].

\subsection{Mobile Mediated Learning}

In 1988, Weiser described mobile mediated learning as incorporating data into the everyday physical word [7], whereby striking distinctions between 'formal' and 'informal' learning became subtle [8]. The meaning of the mobile mediated learning or ubiquity "refers 
not to the idea of 'anytime, anywhere' but to 'widespread', 'just-in-time', and 'when needed' computing power for learners." [9]. Also, this concept provides the students with the chance to experience the theoretical knowledge under the real-life conditions where the various contexts and situations are comprised of adaptive multimedia content. In other words, ubiquitous computing environment enjoys tools which are visible, along with embedded contextual information that provides learners with a highly dynamic education setting so that users can learn through functional objects while practicing them anytime and anywhere [10]. Mobile mediated learning makes a connection between school and non-school education such as museums, galleries, historical houses, libraries, zoological or botanical gardens, science and other cultural centers [8], hence learners' having the chance to experience the right thing at the right place in the right time [9].

In an educational environment, teachers and students can benefit from new advances in ubiquitous computing, employing ubiquitous devices and technologies in the classroom. Actually, young people carry with them mobile devices anywhere and anytime and enjoy playing with new gadgets [11]. Educators and curriculum developers are required to appreciate this reality and adopt "mobile 21 st-century tools for 21st-century learners" [12]. Given the important role that different forms of technology play in everyday life and in language learning in particular, it is important to investigate how different aspects of technology that provides opportunities for mobile mediated language learning affect learner's L2 achievement.

\subsection{Individual Factors and M-learning}

Previous research indicated that individual factors play an important role in language learning. In the same vein, individual factors play a significant role in technology-based language learning as different aspects of technology may cater to different individual factors. With regard to $\mathrm{m}$ - learning two factors that can potentially affect language learning are perceived satisfaction and perceived usefulness of learners.

Learner satisfaction is regarded as obtaining all the advantages a learner seeks to receive from learning, in terms of his behavioral beliefs and attitudes [13]. Perceived satisfaction is a key factor which emanates from performing a learning task, where the aimed outcomes are enjoyably yielded. Perceived satisfaction, in accordance with Bolliger \& Wasilik [14], is a vital aspect of learning.

Another factor that can be associated with m-learning is the "perceived usefulness of instruction". Perceived usefulness refers to what a person subjectively perceives of the ability of a computer to enhance job performance when completing a task, which affects their perceived usefulness, thereby indirectly impacting on user's technology acceptance. In 2019, Chavoshi and Hamidi divided factors affecting m-learning into four groups: Technological, Pedagogical, Social and Individual. The research results indicated that perceived usefulness is the most effective factor in the acceptance of m-learning in Iran [15].

Based on the above literature review and considering the fact that technology continues to grow in importance as a tool to assist teachers of foreign languages in facilitating and mediating language learning for their students, it can be argued that m-learning is affected by various factors. However these factors are relatively less understood and future research is needed to better understand the effects of different aspects of mobile mediated learning including omnipresence, context customization, interactivity, perceived self-efficacy and mlearning motivation on L2 learner's perceived satisfaction, perceived usefulness of m-learning and also the effects on classroom achievement. The constructs used in this study including mobile mediated language learning and learner characteristics are among the constructs used by Jung [16] and Liaw and Huang [17]. In addition, most previous technology assisted L2 
studies examined the role of different forms of technology in L2 learning and ignored how individual factors affect technology-based instructions.

\subsection{Research Questions}

Based on the objectives of the current study and the research models presented above, the following research questions guide the present study:

1. Do different aspects of mobile mediated learning affect learners' perceived satisfaction of language learning?

2. Do different aspects of mobile mediated learning affect learners' perceived usefulness of language learning?

3. Is learners' classroom achievement influenced by their perceived satisfaction with mlearning?

4. Is learners' classroom achievement influenced by their perceived usefulness of m-learning?

\section{METHODS}

\subsection{Research Model}

Figure 1 shows the proposed model of this study. The model has five constructs for mobile mediated learning including omnipresence, context customization, interactivity, perceived self-efficacy and m-learning motivation. The aim of the present study is to investigate how these aspects related to mobile mediated learning along with learners' perceived satisfaction and perceived usefulness would affect learners' achievement in L2 classroom. A description of the main variables examined in the present study follows.

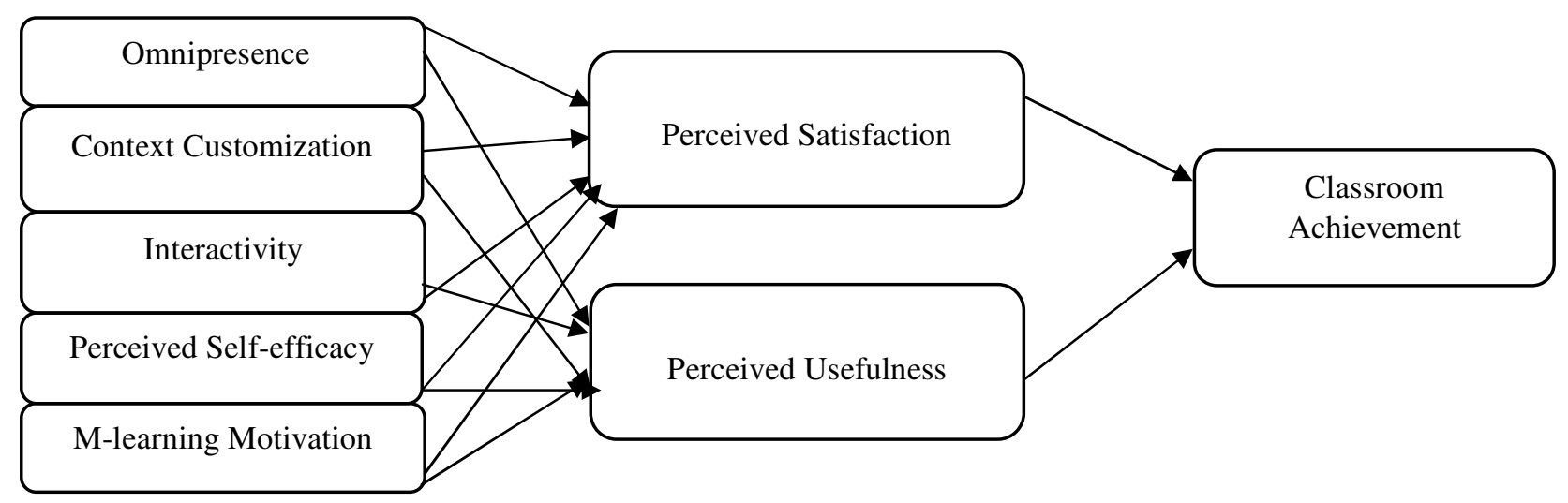

Figure 1. Research Model

\section{Omnipresence}

The first construct for mobile mediated learning investigated in the present study is omnipresence. In this study, omnipresence is defined as English language learners' (ELLs) perception of the degree of personalized and uninterrupted connections offered by m-learning as well as the communication between students and other students and/or the contexts of learning [18].

\section{Context Customization}

Customization, the second construct proposed for mobile mediated learning, is defined in this study as the extent to which m-learning presents EFL learners with efficient content based on the learners' needs and learning context [19], [20]. 


\section{Interactivity}

Based on the proposed research model examined in the present study, interactivity is regarded as the third construct for mobile mediated learning. Wang [21] defined interactivity as the interaction between ELLs and learning resources.

\section{Perceived Self-efficacy}

According to the Social Cognitive Theory, the concept of perceived self-efficacy is the belief that one can conduct novel or difficult tasks and obtain desired outcomes [22].

\section{M-Learning Motivation}

Mobile learning motivation investigated in the present study's model is the learner's tendency to acquire new behavioral patterns in terms of the use of a new technology [23].

\subsection{Participants}

The participants of the study include a sample of 150 high school students in ShirazIran. All students were in grade ten at the time of the study. All the students were female and 16 years old. The textbook taught to students at the time of the present study was VISION 1. The students were enrolled in the first year of secondary school. They had studied English for three years during primary education and could be considered as intermediate-level EFL learners. The students were motivated to learn English and participated voluntarily. A virtual group was made for them on the Telegram to have prompt accessibility to be able to share the additional book materials such as voice files, video clips, power points, etc. On the other hand, their assignments were reminded and emphasized by the admin of the group who was their teacher.

\subsection{Data Collection Procedures}

The participants of this study were added to a Telegram group through which they could send their assignment including writing pieces and audio files and receive feedback on their assignments. Also, they could ask questions about their problems and receive answers. After participating in 12 mobile-assisted language learning sessions, the participants received a questionnaire that included several sections. The questionnaire was intended to measure a) learners' perceptions about different aspects of mobile mediated learning including (omnipresence, context customization, interactivity, perceived self-efficacy, and m-learning motivation) b) learners' perceived satisfaction with the mobile-assisted language learning program (m-learning) c) learners' perceived usefulness of that program. In order to eradicate possible misunderstandings or confusion on the side of the participants, the translated versions of the questionnaires were used to collect the data. After obtaining learners' scores, statistical analysis was run using structural equation modeling. Figure 1 represents the model which was used in this study to perform structural equation modeling for analyzing learners' scores.

All learners were required to use Telegram for the above purposes on a daily basis. Before administering the questionnaire, all participants were given an oral description of the objectives and procedures of the study in order to make the instructions clear thoroughly. Three instruments (explained in detail below) were administered in one session: first, aspects of mobile mediated learning questionnaire, then learners' perceived satisfaction and perceived usefulness of $\mathrm{m}$ - learning questionnaire. In addition, the final exam results of the participants were gathered to be included for further data analysis. A description of the instruments used in the present study for data collection follows. 


\subsection{Data Collection Instruments}

\subsubsection{Aspects of Mobile Mediated learning Questionnaire}

Aspects of mobile mediated learning questionnaire used in this study was adapted from Jung [16] and Liaw \& Huang [17]. The questionnaire included five aspects namely omnipresence, context customization, interactivity, perceived self-efficacy, and m-learning motivation. Among these five aspects, four were chosen from Jung [16] and one was chosen from Liaw \& Huang [17]. Each respondent is asked to indicate the extent to which he or she agreed with each item on a five-point Likert-type scale ranging from "strongly disagree" (1) to "strongly agree" (5). The reliability of the new questionnaire with 16 points was calculated and Cronbach's Alpha 0.93 was obtained.

\subsubsection{Perceived Satisfaction and Perceived Usefulness Questionnaire}

This questionnaire employed to measure learners' perceived satisfaction and also perceived usefulness of m-learning was developed by Liaw \& Huang [17]. It consists of 11 items. The students completed the questionnaire on a 5-point, Likert scale that ranges from "strongly disagree" (1) to "strongly agree" (5). The amount of Cronbach's alpha coefficient of this questionnaire with 11 points generally as measured in the present study was 0.92 .

\subsubsection{Classroom Achievement Scores of the Students}

Classroom achievement scores of the students were taken from their final exam results. The achievement of learners was investigated through their performance on the final exam of that semester. The achievement test had 65 questions and included the four language skills along with vocabulary and grammar. This test was a teacher-made test and was constructed by the classroom teacher based on the contents the students learned during the semester in the class.

\subsection{Data Analysis}

This study adopted an explanatory design considering a sample of Iranian EFL's students to identify the effects of mobile mediated language learning on EFL learners' perceived satisfaction and perceived usefulness and also their effect on final classroom achievement using Structural Equation Modeling. This method is a multivariate statistical analysis used to analyze structural relations. It is the synthesis of factor analysis and multiple regression analysis, which is used for the study of the structural relationship between measured variables and latent constructs. Also, it estimates the multiple and interrelated dependence in a single analysis [24].

The proposed research model of this paper incorporates mobile mediated learning aspects (omnipresence, context customization, interactivity, perceived self-efficacy, and mlearning motivation) as well as learners' perceived satisfaction and perceived usefulness and their effects on EFLs' classroom achievement. Also, the study assesses the effect of learners' perceived satisfaction and perceived usefulness on classroom achievement in the context of English learning.

For investigating the effects of different aspects of mobile mediated learning on learners' perceived satisfaction and perceived usefulness of m-learning and L2 achievement, Structural Equation Modeling was conducted using AMOS software. 
3.6. ASSESSMENT OF THE MEASUREMENT MODEL

\subsubsection{Validity and Reliability of the Aspects of Mobile Mediated learning Questionnaire}

Confirmatory factor analysis was run to investigate the validity of mobile mediated learning questionnaire. The results indicated that the model explained $63.35 \%$ of the total variance of the scores. The following table displays factor loads belonging to specific factors. As table 1 shows the Omnipresence and Context Customization factors accounted for $16.93 \%$ and $15.26 \%$ of the total variance respectively. Moreover, Interactivity, Perceived selfefficacy, and M-learning motivation factors explained $14.19 \%, 10.96 \%$ and $6.01 \%$ accordingly.

Table 1

Factor Analysis of Aspects of Mobile Mediated Learning Questionnaire Dimensions

\begin{tabular}{|c|c|c|c|c|c|}
\hline Questions & Omnipresence & $\begin{array}{c}\text { Context } \\
\text { Customization }\end{array}$ & Interactivity & $\begin{array}{l}\text { Perceived } \\
\text { Self- } \\
\text { efficacy } \\
\end{array}$ & $\begin{array}{c}\text { M- } \\
\text { learning } \\
\text { Motivation }\end{array}$ \\
\hline Q1 & 0.55 & & & & \\
\hline Q2 & 0.60 & & & & \\
\hline Q3 & 0.64 & & & & \\
\hline Q4 & & 0.63 & & & \\
\hline Q5 & & 0.66 & & & \\
\hline Q6 & & 0.58 & & & \\
\hline Q7 & & & 0.59 & & \\
\hline Q8 & & & 0.60 & & \\
\hline Q9 & & & 0.56 & & \\
\hline Q10 & & & & 0.58 & \\
\hline Q11 & & & & 0.62 & \\
\hline Q12 & & & & 0.55 & \\
\hline Q13 & & & & 0.65 & \\
\hline Q14 & & & & & 0.55 \\
\hline Q15 & & & & & 0.56 \\
\hline Q16 & & & & & 0.48 \\
\hline $\begin{array}{c}\text { Special } \\
\text { Value }\end{array}$ & 3.38 & 3.05 & 2.83 & 2.19 & 1.20 \\
\hline Variance $\%$ & 16.93 & 15.26 & 14.19 & 10.96 & 6.01 \\
\hline $\begin{array}{c}\text { Total } \\
\text { Variance }\end{array}$ & \multicolumn{5}{|c|}{63.35} \\
\hline
\end{tabular}

With regards to the reliability, Table 2 indicates Cronbach's alpha values for the five aspects of mobile mediated learning questionnaire.

Table 2

\section{Cronbach's Alpha Coefficients of Aspects of Mobile Mediated Learning Questionnaire Dimensions}

\begin{tabular}{|c|c|c|}
\hline Factor & $\begin{array}{c}\text { Number of } \\
\text { points }\end{array}$ & $\begin{array}{c}\text { Cronbach's Alpha } \\
\text { Coefficients }\end{array}$ \\
\hline Omnipresence & $\mathbf{3}$ & $\mathbf{0 . 8 2}$ \\
\hline Context Customization & $\mathbf{3}$ & $\mathbf{0 . 7 4}$ \\
\hline Interactivity & $\mathbf{3}$ & $\mathbf{0 . 8 0}$ \\
\hline Perceived Self-efficacy & $\mathbf{4}$ & $\mathbf{0 . 8 7}$ \\
\hline M-learning Motivation & $\mathbf{3}$ & $\mathbf{0 . 7 7}$ \\
\hline
\end{tabular}




\subsubsection{Validity and Reliability of the Learners' Perceived Satisfaction and Perceived Usefulness Questionnaire}

Confirmatory factor analysis of Learners' Perceived Satisfaction and Perceived Usefulness Questionnaire indicated the total value of $60.63 \%$. Furthermore, the questions belonging to Perceived Satisfaction had $33.76 \%$ variance while Perceived Usefulness items accounted for $26.87 \%$ variance. Table 3 shows factor loadings belonging to the specific items.

Table 3

\section{Factor Analysis of Perceived Satisfaction and Perceived Usefulness Questionnaire Dimensions}

\begin{tabular}{|c|c|c|}
\hline Questions & $\begin{array}{l}\text { Perceived } \\
\text { Satisfaction }\end{array}$ & $\begin{array}{l}\text { Perceived } \\
\text { Usefulness } \\
\end{array}$ \\
\hline Q1 & 0.67 & \\
\hline Q2 & 0.54 & \\
\hline Q3 & 0.79 & \\
\hline Q4 & 0.60 & \\
\hline Q5 & 0.68 & \\
\hline Q6 & & 0.54 \\
\hline Q7 & & 0.59 \\
\hline Q8 & & 0.62 \\
\hline Q9 & & 0.60 \\
\hline Q10 & & 0.54 \\
\hline Q11 & & 0.58 \\
\hline Special Value & 4.54 & 4.12 \\
\hline Variance $\%$ & 33.76 & 26.87 \\
\hline Total Variance & \multicolumn{2}{|c|}{60.63} \\
\hline
\end{tabular}

With regards to the reliability, Table 4 shows Cronbach's alpha values for Learners' Perceived Satisfaction and Perceived Usefulness Questionnaires.

Table 4

\section{Cronbach's Alpha Coefficients of Learners' Perceived Satisfaction and Perceived Usefulness Questionnaire Dimensions}

\begin{tabular}{|c|c|c|}
\hline Factor & Number of points & $\begin{array}{c}\text { Cronbach's Alpha } \\
\text { Coefficients }\end{array}$ \\
\hline Perceived Satisfaction & 5 & 0.84 \\
\hline Perceived Usefulness & 6 & 0.89 \\
\hline
\end{tabular}

\subsection{Analysis of the Structural Model}

In this study, hypotheses were tested by using AMOS version 21 software with maximum likelihood. First, raw data is usually converted into a covariance matrix or a correlation of the relationships between the observed variables, before being used as inputs of the computer program. The fit dimensions for a model are converted by comparing the covariance matrix or the correlation between the relationships between the observed variables. Fit measurements are obtained by comparing the estimated covariance matrix for the population with the sample covariance matrix calculated from the data. Of course, fitting models with data doesn't necessarily mean that the model is correct. Because there may still be another model that matches the data as well and the same. When a model is precisely 
defined and has the same characteristics and its estimation and testing are possible, then there are many ways to assess its fitness.

The analyzed model of the main hypothesis of this research is presented in standardized ratios in Figures 2.

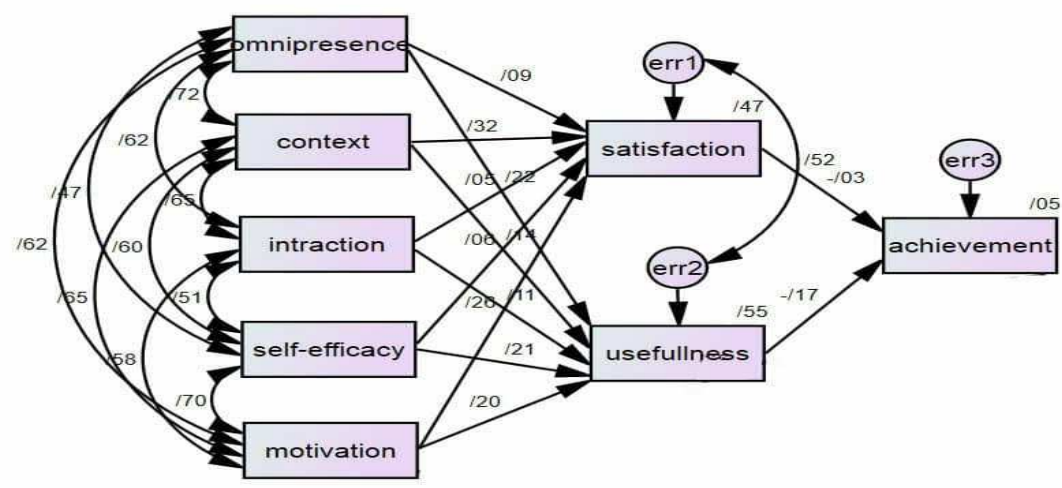

Figure 2. The Analyzed Model of the Main Hypothesis of the Present Study in Standardized Mode

Conceptual model fitting indices the main hypothesis of the present study is shown in Table 5. According to the fit indices reported, the conceptual model of the main hypothesis of this research had a favorable fitting level.

Table 5

Fit Indices, the Main Hypothesis of the Present Study

\begin{tabular}{|c|c|c|c|c|c|c|}
\hline Fit Indices & $\begin{array}{c}\text { Chi- } \\
\text { Square/ DF }\end{array}$ & RMSEA & NFI & TLI & CFI & RFI \\
\hline $\begin{array}{c}\text { Conceptual } \\
\text { Model of } \\
\text { Present Study }\end{array}$ & 1.72 & 0.07 & 0.99 & 0.96 & 0.99 & 0.93 \\
\hline $\begin{array}{c}\text { Desirable } \\
\text { Situation }\end{array}$ & $<3$ & $<0.08$ & & & & \\
\hline
\end{tabular}

\section{FINDINGS}

The effect of different aspects of mobile mediated learning including omnipresence, context customization, interactivity, perceived self-efficacy and m-learning motivation on learners' perceived satisfaction with m-learning was tested separately and is presented in Table 6. As the table indicates, two aspects that affect perceived satisfaction with m-learning are Context customization and m-learning motivation. It means that an increase in the standard deviation of the Context customization and m-learning motivation would increase the standard deviation of perceived satisfaction.

Table 6

\section{Direct Effect Indicator of Different Aspects of Mobile Mediated Learning on Learners' Perceived Satisfaction}

\begin{tabular}{|c|c|c|c|c|c|}
\hline $\begin{array}{c}\text { Independent } \\
\text { variable }\end{array}$ & $\begin{array}{c}\text { Dependent } \\
\text { variable }\end{array}$ & $\begin{array}{c}\text { Non- } \\
\text { Standard } \\
\text { effect }\end{array}$ & $\begin{array}{c}\text { Standard } \\
\text { Effect }\end{array}$ & $\begin{array}{c}\text { Significant } \\
\text { level }\end{array}$ & Result \\
\hline
\end{tabular}




\begin{tabular}{|c|c|c|c|c|c|}
\hline Omnipresence & \multirow{5}{*}{$\begin{array}{c}\text { Perceived } \\
\text { Satisfaction }\end{array}$} & 0.08 & 0.09 & 0.32 & No \\
\hline $\begin{array}{c}\text { Context } \\
\text { customization }\end{array}$ & & 0.30 & 0.32 & 0.01 & Yes \\
\hline Interactivity & & 0.04 & 0.05 & 0.01 & No \\
\hline $\begin{array}{c}\text { Perceived } \\
\text { self-efficacy }\end{array}$ & & 0.05 & 0.06 & 0.46 & No \\
\hline $\begin{array}{l}\text { M-learning } \\
\text { motivation }\end{array}$ & & 0.23 & 0.26 & 0.01 & Yes \\
\hline
\end{tabular}

Table 7 also indicates the effect of different aspects of mobile mediated learning including omnipresence, context customization, interactivity, perceived self-efficacy and mlearning motivation on learner's perceived usefulness of m-learning separately. As shown, omnipresence, perceived self-efficacy, and m-learning motivation are three aspects that affect perceived usefulness with m-learning.

Table 7

\section{Direct Effect Indicator of Different Aspects of Mobile Mediated Learning on Learners' Perceived Usefulness}

\begin{tabular}{|c|c|c|c|c|c|}
\hline $\begin{array}{c}\text { Independent } \\
\text { variable }\end{array}$ & Dependent variable & $\begin{array}{c}\text { Non- Standard } \\
\text { effect }\end{array}$ & $\begin{array}{c}\text { Standard } \\
\text { Effect }\end{array}$ & $\begin{array}{c}\text { Significant } \\
\text { level }\end{array}$ & Result \\
\cline { 1 - 4 } Omnipresence & & 0.20 & 0.21 & 0.01 & Yes \\
\cline { 1 - 4 } $\begin{array}{c}\text { Context } \\
\text { customization }\end{array}$ & & 0.14 & 0.14 & 0.12 & No \\
\cline { 1 - 4 } Interactivity & Perceived Usefulness & 0.10 & 0.11 & 0.14 & No \\
\cline { 3 - 6 } $\begin{array}{c}\text { Perceived } \\
\text { self-efficacy }\end{array}$ & & 0.17 & 0.21 & 0.01 & Yes \\
\cline { 3 - 6 } $\begin{array}{c}\text { M-learning } \\
\text { motivation }\end{array}$ & & 0.18 & 0.20 & 0.02 & Yes \\
\cline { 3 - 6 } & & & & & \\
\hline
\end{tabular}

Moreover, table 8, displays the amount of the standard direct effect of the learner's perceived satisfaction with m-learning on learner's classroom achievement. As presented in this table, the value of the standard direct effect of the learner's perceived satisfaction with mlearning on learner's classroom achievement is -0.02 and non-significant.

Table 8

\section{Direct Effect Indicator of Learners' Perceived Satisfaction on Classroom Achievement}

\begin{tabular}{|l|c|c|c|c|c|}
\hline $\begin{array}{c}\text { Independent } \\
\text { variable }\end{array}$ & Dependent variable & $\begin{array}{c}\text { Non- } \\
\text { Standard } \\
\text { effect }\end{array}$ & $\begin{array}{c}\text { Standard } \\
\text { Effect }\end{array}$ & $\begin{array}{c}\text { Significant } \\
\text { level }\end{array}$ & Result \\
\hline $\begin{array}{l}\text { Perceived } \\
\text { Satisfaction }\end{array}$ & $\begin{array}{c}\text { Classroom } \\
\text { Achievement }\end{array}$ & -0.08 & -0.02 & 0.82 & No \\
\hline
\end{tabular}

Finally, Table 9, specifies the amount of the standard direct effect of the learner's perceived usefulness of m-learning on learner's classroom achievement. As presented in this table, the value of the standard direct effect of the learner's perceived usefulness of mlearning on learner's classroom achievement is -0.17 and non-significant. 
Table 9

Direct Effect Indicator of Learners' Perceived Usefulness on Classroom Achievement

\begin{tabular}{|l|c|c|c|c|l|}
\hline $\begin{array}{c}\text { Independent } \\
\text { variable }\end{array}$ & Dependent variable & $\begin{array}{c}\text { Non- } \\
\text { Standard } \\
\text { effect }\end{array}$ & $\begin{array}{c}\text { Standard } \\
\text { Effect }\end{array}$ & $\begin{array}{c}\text { Significant } \\
\text { level }\end{array}$ & Result \\
\hline $\begin{array}{l}\text { Perceived } \\
\text { Usefulness }\end{array}$ & $\begin{array}{c}\text { Classroom } \\
\text { Achievement }\end{array}$ & -0.47 & -0.17 & 0.18 & No \\
\hline
\end{tabular}

\section{DISCUSSION}

The aim of the present study was to investigate the understanding of mobile mediated language learning among Iranian EFL learners. In fact, in this study the effects of different aspects of mobile mediated learning on learners' perceived satisfaction and also, perceived usefulness of m-learning and their classroom achievement were examined. In addition, the other objective of this study was to examine the effect of learners' perceived satisfaction and perceived usefulness on classroom achievement. The findings of the Structural Equation Modeling ensure adequate reliability and validity for all the variables of the measurement model.

The current study's first research question refers to the effect of different aspects of mobile mediated learning including omnipresence, context customization, interactivity, perceived self-efficacy and m-learning motivation on learners' perceived satisfaction with mlearning. The findings show that due to amounts of standard direct effect of different aspects of mobile mediated learning on learners' perceived satisfaction; omnipresence (0.09), interactivity (0.05), and perceived self-efficacy (0.06) did not influence perceived satisfaction, but context customization (0.32), and m-learning motivation (0.26) affected learners' perceived satisfaction with m-learning.

The results support previous research that it is more likely for those ELLs who see mlearning as relevant to their learning outcomes to be motivated to actively explore it as a technological learning option, suggesting that ELLs who consider m-learning as fitting their learning have more chance of being satisfied because of context customization [25], [16]. The results also show that learners' satisfaction may be increased by the motivation of learners thorough m-learning [16], [26]. The results do not provide support for previous research that omnipresence, interactivity, and perceived self-efficacy significantly affect learners' satisfaction [27], [16], [17]. But the results confirm the findings of Ramayah, Ahmad and Hong [28] indicating that computer self-efficacy did not affect user satisfaction in electronictraining.

The second research question asked if learner's perceived usefulness of m-learning is influenced by different aspects of mobile mediated learning including omnipresence, context customization, interactivity, perceived self-efficacy, and m-learning motivation. The data gathered for this question showed that due to amounts of standard direct effect of different aspects of mobile mediated learning on perceived usefulness; omnipresence $(0.21)$, perceived self-efficacy (0.21), and m-learning motivation (0.20) had an effect on perceived usefulness, but context customization (0.14), and interactivity (0.11) didn't affect learner's perceived usefulness.

The results show omnipresence, a synonym for ubiquity, reflects communication and connectivity in learning environments anytime, anywhere and affects perceived usefulness of learners. Besides, the results support previous research that self-efficacy affects perceived usefulness of learners [17], [29]. The findings also show that mobile learning motivation of participants affects their perceived usefulness. 
The third and fourth research question asked if learner's classroom achievement is influenced by their perceived satisfaction and perceived usefulness of m-learning or not. According to these research questions, the values of standard direct effect showed that learner's classroom achievement is not influenced by their perceived satisfaction (-0.02), and perceived usefulness $(-0.17)$ of m-learning. The findings do not confirm the previous studies that those learners who are satisfied with m-learning and perceive the usefulness of relevant technologies in given learning environments show a better performance in learning [2], [30], [4].

\section{CONCLUSIONS AND PROSPECTS FOR FURTHER RESEARCH}

The purpose of this study was to investigate the understanding of mobile mediated language learning among Iranian EFL learners. After analyzing the data, these findings were reported; the results indicated that three aspects of mobile mediated learning including omnipresence, interactivity, and perceived self-efficacy didn't have any effect on learners' perceived satisfaction, but the two other aspects namely context customization and m-learning motivation had effect on learners' perceived satisfaction. Based on obtained results, among aspects of mobile mediated learning; omnipresence, perceived self-efficacy and m-learning motivation had an effect on learners' perceived usefulness, but context customization and interactivity didn't affect learners' perceived usefulness. The findings specified that learner's classroom achievement is not influenced by their perceived satisfaction and perceived usefulness of m-learning.

The use of mobile technology offers additional ways for teachers to facilitate learning for their students. Additionally, mobile devices provide a means for teachers to make the teaching process more productive and to measure the progress of their students. Smart devices may provide unique opportunities for learners to practice the language through the use of different mobile applications and by communicating with others.

Furthermore, the findings of this study highlight the importance of m-learning for L2 learning, which provides educators and EFL material developers with important insights into these learners' behaviors. In addition, the results will provide educators and learners with useful information about m-learning in the context of English education in Iran. Last but not least, this leads to an intimate and close relationship between the teacher and the students.

Although the researcher has made a lot of attempts to minimize the pitfalls of this study, there are some limitations. The population of this study was limited to one city, only Shiraz. Hence, it might not be the true example of Iranian EFL learners and thus the results cannot be generalized thoroughly. The data gathered from grade 10 high school students. Some students attended English classes in other institutes, so students had different background knowledge. Nevertheless, this difference would affect the results. In this study we only considered the effects of some aspects of mobile mediated learning on learners' perceived satisfaction and perceived usefulness with m-learning, therefore future studies by the use of other characteristics are suggested.

\section{REFERENCES (TRANSLATED AND TRANSLITERATED)}

[1] N. Garrett, "Technology in the service of language learning: trends and issues," republication from The Modern Language Journal, vol. 75, pp. 74-101, 1991. The Modern Language Journal, vol. 93, no. s1, pp. 697-718, 2009. doi:10.1111/j.1540-4781.2009.00968.x (in English).

[2] Y. M. Song, S. H. Kim, and H. J. Jung, "The effect of M-learning environment on perceived usefulness, satisfaction, and performance in English learning," Business Education Review, vol. 57, pp. 275-302, 2009 (in English). 
[3] P. G. Shotsberger and R. Vetter, "How mobile wireless technologies will changes web-based instruction and training," Educational Technology, vol. 40, no. 5, pp. 49-52, 2000 (in English).

[4] W. H. DeLone and E. R. Mclean, "The DeLone and McLean model of information systems success: A ten-year update," Journal of Management Information Systems, vol.19, no. 4, pp. 9-30, 2003 (in English).

[5] C. Lewis, "Driving factors for e-learning: an organizational perspective," Perspectives, vol. 6, no. 2, pp. 50-54, 2002 (in English).

[6] M. J. Ferreira, F. Moreira, C.S. Pereira, and N. Durão, "The Role of Mobile Technologies in the Teaching/learning Process Improvement in Portugal," Paper presented at ICERI 2015 Conference, Seville, Spain, 2015 (in English).

[7] M. Weiser, "Hot Topics: Ubiquitous Computing." Computer, vol. 26, no.10, pp.71-72, 1993 (in English).

[8] J. Wishart, and P. Triggs, "Museum Scouts: Exploring how schools, museums and interactive technologies can work together to support learning." Computers \& Education, vol. 54, pp. 669- 678, 2010 (in English).

[9] H. Peng, Y. Su, C. Chou and C. Tsai, "Ubiquitous knowledge construction: mobile learning redefined and a conceptual framework," Innovations in Education and Teaching International, vol. 46, no.2, pp. 171183, 2009 (in English).

[10] M. Minami, H. Morikawa and T. Aoyama, "The design of naming-based service composition system for ubiquitous computing applications." Paper presented at the 2004 International Symposium on Applications and the Internet Workshops, Tokyo, Japan, January, 2004 (in English).

[11] D.J. Cook, and S.K. Das, "Pervasive computing at scale: Transforming the state of the art," Pervasive and Mobile Computing, vol. 8, no. 1, pp. 22 - 35, 2012 (in English).

[12] C. Norris and E. Soloway, "Handhelds: Getting mobile," District Administration, vol. 44, no. 8, pp. 2024, 2008 (in English).

[13] J. H. Wu, R. D. Tennyson, and T. L. Hsia, "A study of student satisfaction in a blended e-learning system environment," Computers \& Education, vol. 55, no. 1, pp. 155-164, 2010. doi:10.1016/j.compedu.2009.12.012 (in English).

[14] D. U Bolliger and O. Wasilik, "Factors influencing faculty satisfaction with online teaching and learning in higher education," Distance Education, vol. 30, no. 1, pp. 103-116, 2009. doi: 10.1080/01587910902845949 (in English).

[15] A. Chavoshi, \& H. Hamidi, "Social, individual, technological and pedagogical factors influencing mobile learning acceptance in higher education: A case from Iran," Telematics and Informatics, vol. 38, pp. 133165, 2019 (in English).

[16] H.J. Jung, "Ubiquitous Learning: Determinants Impacting Learners' Satisfaction and Performance with Smartphones," Language Learning \& Technology, vol. 18, no. 3, pp. 97-119, 2014. Retrieved from http://lit.msu.edu/issues/october2014/jung.pdf (in English).

[17] SH. SH. Liaw and H. M. Huang, "Perceived satisfaction, perceived usefulness and interactive learning environments as predictors to self-regulation in e-learning environments," Computers \& Education, vol. 60, no.1, pp. 14-24, 2013 (in English).

[18] S. H. Kim, "Moderating effects of job relevance and experience on mobile wireless technology acceptance: Adoption of a smartphone by individuals," Information \& Management, vol.45, no. 6, pp. 387-393, 2008 (in English).

[19] S. Figge, "Situation-dependent service: A challenger for mobile network operators," Journal of Business Research, vol. 57, no. 11, pp. 1416-1422, 2004 (in English).

[20] P. K. Kannan, A. M. Chang and A. B. Whinston, Wireless commerce: Marketing issues and possibilities. Proceedings of the $34^{\text {th }}$ Hawaii International Conference Systems Science, IEEE Computer Society Press, Los Alamitos, 2001 (in English).

[21] H. Wang, A pragmatic framework for promoting interactivity in e-Learning. In T. Reeves \& S. Yamashita (Eds.), Proceedings of World Conference on E-Learning in Corporate, Government, Healthcare, and Higher Education 2006 (pp. 158-163). Chesapeake, VA: Association for the Advancement of Computing in Education, 2006 (in English).

[22] A. Bandura, Exercise of personal and collective efficacy in changing societies. In Self-Efficacy in changing societies, A. Bandura (Ed.), Cambridge University Press, London, 1997 (in English).

[23] T. W. Taris and M. A. J. Kompier, Job demands, job control, strain and learning behavior: Review and research agenda. In A. Stamatios Antoniou, \& C.L. Cooper (Eds), Research companion to organizational health psychology, pp. 132-150. London, UK: Edward Elgar, 2005 (in English).

[24] J. C. Anderson and D. W. Gerbing, "Structural equation modeling in practice: A review and recommended two-step approach," Psychological Bulletin, vol. 103, no. 3, pp. 411-423, 1988 (in English). 
[25] A. Bhattacherjee and C. Sanford, When attitudes don't predict behavior: A study of attitude strength. Proceedings of the 12th Americas Conference on Information Systems, Universidad Autónoma Metropolitana, 2006 (in English).

[26] L. K. Long, C. Z. DuBois and R. H. Faley, "Online training: The value of capturing trainee reactions," Journal of Workplace Learning, vol. 20, no.1, pp. 21-37, 2008 (in English).

[27] B. H. Khan and R. Vega, Factors to consider when evaluating a web-based instruction course: A survey. In B.H. Khan (Ed.), Web-based instruction, pp. 375-379, Englewood Cliffs, NJ: Educational Technology, 1999 (in English).

[28] T. Ramayah, N. H. Ahmad and T. S. Hong, "An Assessment of E-training Effectiveness in Multinational Companies in Malaysia," Educational Technology \& Society, vol. 15, no. 2, pp. 125-137, 2012 (in English).

[29] W. M. Al- Rahimi, N.Alias, M. SH. Othman, A. I. Alzahrani, O. Alfarraj, A. A. Saged and N. SH Abdul Rahman, "Use of E-Learning by University Students in Malaysian Higher Educational Institutions: A Case in Universiti Teknologi Malaysia," IEEE Access, vol. 6, pp. 14268-14276, 2018 (in English).

[30] J. E. Bailey and S. W. Pearson, "Development of a tool for measuring and analyzing computer user satisfaction," Management Science, vol. 29, no. 5, pp. 530-545, 1983 (in English).

Text of the article was accepted by Editorial Team 07.11.2019

\title{
МОБІЛЬНЕ НАВЧАННЯ ПІД ЧАС ВИВЧЕННЯ МОВИ: ПОЗИТИВНЕ СТАВЛЕННЯ УЧНІВ, СПРИЙНЯТА КОРИСНІСТЬ ТА УСПІШНІСТЬ
}

\author{
Марал Азізізі \\ $\mathrm{PhD}$ кандидат за фахом TEFL, викладач англійської мови, кафедра англійської мови \\ Ісламський університет Азад, Ширазська філія, Шираз, Іран \\ Maralazizi.25@gmail.com

\section{Ехсан Разсай} \\ $\mathrm{PhD}$ кандидат за фахом TEFL \\ доцент, кафедра англійської мови, \\ Ісламський університет Азад, Ширазська філія, Шираз, Іран \\ Ehsanrassaei@yahoo.com

\section{Мохаммад Садег Багері} \\ $\mathrm{PhD}$ кандидат за фахом TEFL, доцент, кафедра англійської мови \\ Ісламський університет Азад, Ширазська філія, Шираз, Іран \\ bagheries@gmail.com
}

\begin{abstract}
Анотація. Мобільні технології останнім часом стали одними 3 найбільш важливих напрямків досліджень у сфері освіти. Мобільні технології вважаються цінним ресурсом для навчання і викладання мов і надають безліч практичних можливостей у цьому процесі. Концепція мобільного навчання і його базові структури, його вплив на навчання мовам мало вивчені в іранському контексті. Тому важливо досліджувати, які аспекти мобільного навчання, разом із всюдисущістю, налаштуванням контексту, інтерактивністю, самоефективностю і мотивацією до мобільного навчання, впливають на прагнення оволодіння другою мовою. У даній статті досліджується розуміння мобільного навчання іранськими студентами, які вивчають англійську мову як іноземну (EFL) шляхом дослідження впливу різних аспектів цієї концепції на задоволеність учнів, а також на сприйняту корисність мобільного навчання. Більш того, дане дослідження має на меті вивчення впливу задоволеності учнів і сприйнятої корисності мобільного навчання на їх успішність у класі EFL. 3 цією метою було відібрано 150 учнів EFL, яких додали як групу в Телеграм для проходження 12 сесій мобільного навчання мови, після чого студенти заповнили три анкети, у яких були порушені питання щодо мобільного навчання, а також задоволеності учнів і сприйнятої корисності мобільного навчання. Була запропонована модель дослідження, яка демонструє структуру, розглянуту в статті. Результати моделювання структурних рівнянь показали, що два аспекти мобільного навчання значно впливають на задоволеність учнів, три аспекти - на сприйняту корисність. Крім цього, на успішність учнів у класі не впливає задоволеність учнів і сприйнята корисність мобільного навчання.
\end{abstract}


Ключові слова: мобільне навчання; задоволеність учнів; сприйнята корисність; успішність у класі.

\title{
МОБИЛЬНОЕ ОБУЧЕНИЕ ПРИ ИЗУЧЕНИИ ЯЗЫКА: ПОЗИТИВНОЕ ОТНОШЕНИЕ УЧАЩИХСЯ, ВОСПРИНИМАЕМАЯ ПОЛЕЗНОСТЬ И УСПЕВАЕМОСТЬ
}

\author{
Марал Азизизи \\ PhD кандидат по специальности TEFL, преподаватель английского языка \\ кафедра английского языка, Исламский университет Азад, Ширазский филиал, Шираз, Иран \\ Maralazizi.25@gmail.com

\section{Эхсан Разсай} \\ $\mathrm{PhD}$ кандидат по специальности TEFL, доцент, кафедра английского языка \\ Исламский университет Азад, Ширазский филиал, Шираз, Иран Ehsanrassaei@yahoo.com

\section{Мохаммад Садег Багери} \\ $\mathrm{PhD}$ кандидат по специальности TEFL, доцент, кафедра английского языка \\ Исламский университет Азад, Ширазский филиал, Шираз, Иран bagheries@gmail.com
}

\begin{abstract}
Аннотация. Мобильные технологии в последнее время стали одними из наиболее важных направлений изучения в сфере образования. Мобильные технологии считаются ценным ресурсом для изучения и преподавания языка и предоставляют множество практических возможностей в процессе его обучения. Концепция мобильного обучения и лежащие в ее основе структуры, а также их влияние на изучение языка и преподавание, мало изучены в иранском контексте. Поэтому важно исследовать, какие аспекты мобильного обучения, включая вездесущность, настройку контекста, интерактивность, самоэффективность и мотивацию к мобильному обучению, влияют на стремление изучения второго языка. В данной статье исследуется понимание мобильного обучения иранскими студентами, изучающими английский язык как иностранный (EFL), путем изучения влияния различных аспектов этой концепции на удовлетворенность учащихся, а также на воспринимаемую полезность мобильного обучения. Более того, данное исследование нацелено на изучение влияния удовлетворенности учащихся и воспринимаемой полезности мобильного обучения на их успеваемость в классе EFL. С этой целью было отобрано 150 учащихся EFL, которых добавили как группу в Телеграмм для прохождения 12 сессий мобильного изучения языка, после чего студенты ответили на вопросы трех анкет, в которых были затронуты вопросы по мобильному обучению, а также удовлетворенности учащихся и воспринимаемой полезности мобильного обучения. Была предложена модель исследования, которая демонстрирует структуру, рассмотренную в статье. Результаты моделирования структурных уравнений показали, что два аспекта мобильного обучения оказывают значительное влияние на удовлетворенность учащихся, три аспекта - на воспринимаемую полезность. Кроме этого, на успеваемость учащихся в классе не влияет удовлетворенность учащихся и воспринимаемая полезность мобильного обучения.
\end{abstract}

Ключевые слова: мобильное обучение; удовлетворенность учащихся; воспринимаемая полезность; успеваемость в классе.

\section{$(\mathrm{Cc}) \mathbf{B Y} \mathrm{NC}-\mathrm{SA}$}

This work is licensed under Creative Commons Attribution-NonCommercial-ShareAlike 4.0 International License. 